\title{
Compliance to home-based exercise therapy in elderly patients with knee osteoarthritis
}

\author{
Diz osteoartriti olan yaşlı hastaların ev egzersiz tedavisine uyumu
}

\author{
Saime Ay, ${ }_{1}$ Deniz Evcik, ${ }^{2}$ Yeşim Gökçe-Kutsal, ${ }^{3}$ Füsun Toraman, ${ }^{4}$ Müesser Okumuş, ${ }^{5}$ Sibel Eyigör, ${ }^{6}$ Nilay Şahin ${ }^{7}$ \\ ${ }^{1}$ Department of Physical Medicine and Rehabilitation, Medical Faculty of Ufuk University, Ankara, Turkey \\ ${ }^{2}$ Department of Therapy and Rehabilitation, Haymana Vocational Health School, Ankara University, Ankara, Turkey \\ ${ }^{3}$ Department of Physical Medicine and Rehabilitation, Medical Faculty of Hacettepe University, Ankara, Turkey \\ ${ }^{4}$ Department of Physical Medicine and Rehabilitation, Antalya Training and Research Hospital, Antalya, Turkey \\ ${ }^{5}$ Department of Physical Medicine and Rehabilitation, Ankara Training and Research Hospital, Ankara, Turkey \\ ${ }^{6}$ Department of Physical Medicine and Rehabilitation, Medical Faculty of Ege University, İzmir, Turkey \\ ${ }^{7}$ Department of Physical Medicine and Rehabilitation, Medical Faculty of Meram University, Konya, Turkey
}

Received / Geliş tarihi: June 2015 Accepted / Kabul tarihi: November 2015

\begin{abstract}
Objectives: This study aims to evaluate the compliance to home-based exercise regimen by elderly patients with osteoarthritis of the knee.

Patients and methods: Between May 2012 and May 2013 year, a total of 72 patients (54 females, 18 males) over 65 years old with knee osteoarthritis admitted to the Physical Medicine and Rehabilitation outpatient clinic were included in the study. The patients were given a home-based exercise program. They were recommended to perform the exercises 10 times twice a day, for a month. We evaluated the patients' demographic data, comorbid diseases, whether they exercised previously and compliance to exercise.

Results: All patients' home exercise program compliance was $62.5 \%$. Males were more compliant than female patients and high education and comorbidity were also associated with poor compliance.

Conclusion: The compliance of the geriatric patients to home-based exercise program is difficult and multiple variables affect the compliance. Keywords: Compliance; exercise; geriatric.
\end{abstract}

\section{$\ddot{O Z Z}$}

Amaç: Bu çalışmada diz osteoartriti olan yaşlı hastaların ev egzersiz programına uyumları değerlendirildi.

Hastalar ve yöntemler: Mayıs 2012 ve Mayıs 2013 tarihleri arasında Fiziksel Tip ve Rehabilitasyon polikliniğine diz osteoartriti nedeni ile başvuran 65 yaş üstü 72 hasta (54 kadın, 18 erkek) çalışmaya dahil edildi. Hastalara ev egzersiz programı verildi. Egzersizleri bir ay boyunca günde iki kez 10 tekrar şeklinde yapmaları önerildi. Hastaların demografik verileri, eşlik eden hastalıkları, önceden egzersiz yapıp yapmadıkları ve egzersiz uyumları değerlendirildi.

Bulgular: Tüm hastaların ev egzersiz programına uyumları \%62.5 idi. Erkekler kadın hastalara kıyasla egzersiz programına daha uyumlu iken yüksek eğitim düzeyi ve eşlik eden hastalıkların varlığı zayıf uyum ile ilişkiliydi.

Sonuç: Yaşlı hastaların ev egzersiz programlarına uyumu zordur ve birçok değişken uyumu etkilemektedir.

Anahtar sözcükler: Uyum; egzersiz; yaşlı.

Osteoarthritis (OA) is the most common chronic joint disorder causing pain and deformities and is an important cause of morbidity in elderly people. The knee is one of the most commonly involved joints and causes significant functional limitations. ${ }^{[1]}$
The therapeutic management for OA patients is often divided into three main categories: nonpharmacological, pharmacological and surgical methods. Non-pharmacological treatment modalities recommended by European League Against

Corresponding author / İletişim adresi: Saime Ay, MD. Ufuk Üniversitesi Tıp Fakültesi, Fiziksel Tıp ve Rehabilitasyon Anabilim Dalı, 06520 Balgat, Ankara, Turkey. e-mail / e-posta: saimeay@yahoo.com 
Rheumatism (EULAR) for knee OA treatment emphasize patient education programs, strategies for coping with the disease, weight loss and exercise programs. Exercise programs have become very popular in recent years. ${ }^{[2]}$ Therapeutic exercise is one of the most commonly prescribed treatments for $\mathrm{OA}$ in elderly people, and the efficacy of therapeutic exercise can be established. The evidence for combined exercise programmes, including range of motion (ROM), stretching, isometric, isotonic and isokinetic strengthening exercises targeting knee region muscles are commonly used in the treatment. ${ }^{[2,3]}$ Whereas compliance to exercise therapy is as low as compliance with other medical regimes, the terms "compliance" and "adherence" tend to be used interchangeably. The term compliance means adhering to the medication prescription regimen and exercise program..$^{[4,5]}$

Numerous attempts can be made in order to assure patient compliance. Poor compliance is associated with other illnesses, a longer duration of therapy, physical activity, time conflicts, sociodemographic variables, cognitive-emotional, behavioral, cultural, economic and social symptoms. ${ }^{[4,6]}$ Patients who generally take part in exercise seem to have a higher compliance level with new exercise programs. In home-based exercises, the level of complexity and intensity of programs have a correlation on patients' compliance, as the complexity increases the compliance decreases. Also compliance decreases over time due to the decrease in patients' motivations as a result of symptom relief. ${ }^{[4,6]}$

Various studies showed beneficial effects of home-based exercise programs in musculoskeletal disorders. ${ }^{[7,8]}$ However, the effectiveness of an exercise treatment may depend on patients' compliance. The aim of this study was to evaluate the compliance of home based exercise program in elderly patients with knee osteoarthritis.

\section{PATIENTS AND METHODS}

This cross-sectional study was conducted by the Geriatric Rehabilitation Research Group of the Turkish Physical Medicine and Rehabilitation. A total of 72 patients (54 females, 18 males), who were over 65 years of age, with knee OA were included in this study between May 2012 and May 2013. The diagnosis of OA was based on the criteria of American College of Rheumatology (ACR). ${ }^{[9]}$ The patients' demographic properties, comorbid diseases (hypertension, diabetes mellitus, osteoporosis, discopathy, gastritis) and history of exercise were recorded.
After physical examinations took place, all subjects had weight-bearing anteroposterior X-rays of the knees taken. These were evaluated according to the Kellgren scale and the patients having grades II and III OA were included the study. ${ }^{[10]}$ Patients having effusion in knees, previous knee arthroplasty, severe cardiovascular diseases, neurologic diseases, malignancy and grade IV OA according to Kellgren and Lawrence criteria were excluded. Before treatment all participants were informed of the study and signed written informed consent. The study was approved by the University of Ufuk Human Research Ethics Committee. The study was conducted in accordance with the principles of the Declaration of Helsinki.

Patients received a home-based exercise program, which included written materials including exercises and learned how to properly perform the exercises under the supervision of a physician. Each exercise program included range of motion (ROM), isometricisotonic quadriceps exercises.

Exercise 1: Patients bend their knees backwards in order lying prone

Exercise 2: Patients contract their quadriceps muscles by pushing a towel roll for six seconds before relaxing for five seconds and their knees were extended and their ankles were dorsiflexed while sitting on a flat floor.

Exercise 3: Patients extend their leg slowly, hold for six seconds then lower slowly when sitting on a chair.

Exercise 4: Patients push legs toward each other in a cross position for five seconds and repeated the same movement by changing the legs while sitting on a chair.

The exercises were recommended to be performed twice a day, with 10 repetitions for one month. Patients signed the exercises which they performed daily on a given exercise follow-up table. The period spent in exercise was recorded. The follow-up schedule was delivered to physician at the end of the month.

The compliance of the patients was found by dividing the number of the successfully performed exercise to the total number of the exercises recommended and multiplied by a hundred. Patients having values above $50 \%$ were recognized as being compliant, having values $50 \%$ and below were considered as noncompliance.

\section{Statistical analysis}

The means and standard deviations and frequencies were given as descriptive statistics. Statistical analyses were performed after the patients were divided into 
compliance and noncompliance groups. Comparison of the two groups was carried out with the chi-square and Mann-Whitney $U$ test. A level of significance of $\mathrm{p}<0.05$ was accepted for this study. The power analyses were completed using the chi-square test power analysis. All analyses were performed using SPSS for Windows version 16.0 software (SPSS Inc., Chicago, IL, USA).

\section{RESULTS}

All patients completed the study and no one suffered any adverse effects. The majority of the patients had grade III (\%68) osteoarthritis based on radiologic criteria. The demographic properties of the patients were shown in Table 1.

The ratio of compliance of patients with the home exercise program was $62.5 \%$. Male and female sex distribution was not homogeneous in both the compliance and the non-compliance groups ( $\mathrm{p}=0.035)$. Male and female patients' compliance averages in the compliance group were $83.3 \%$ and $55.6 \%$ respectively. Males were more compliant than female patients. On the other hand, high levels of educational attainment and comorbidity were associated with poor compliance (Table 2). There were statistically significant differences between the compliance and noncompliance groups regarding gender $(p=0.035)$, previous history of exercise $(\mathrm{p}=0.002)$ and exercise duration $(\mathrm{p}=0.001)$; except age $(\mathrm{p}=0.575)$, education level $(\mathrm{p}=0.482)$ and comorbidity $(\mathrm{p}=424)$ (Table 3$)$.

Post hoc power analysis was calculated for this cross sectionally designed study from the previous history of exercise. A sample size of 72 achieves $99 \%$ power to detect an effect size (W) of 0.5916 using a three degrees of freedom chi-square test with a significance level (alpha) of 0.05000 .

Table 1. Demographic and clinical properties of the patients $(\mathrm{n}=72)$

\begin{tabular}{lccr}
\hline & $\mathrm{n}$ & $\%$ & Mean \pm SD \\
\hline Age (years) & & & $70.6 \pm 5.2$ \\
Gender & & & \\
$\quad$ Female & 54 & & \\
$\quad$ Male & 18 & & \\
Education level & & & \\
$\quad$ Low $(<8$ years) & 54 & 75 & \\
$\quad$ High $(>8$ years) & 18 & 25 & \\
Comorbidity & & & \\
$\quad$ Single disease & 21 & 29 & \\
$\quad$ More than one disease & 51 & 71 & \\
Compliance & & 62.5 & \\
\hline
\end{tabular}

SD: Standard deviation.

\section{DISCUSSION}

Osteoarthritis is one of the most common musculoskeletal problems and is an important cause of morbidity in elderly people. Exercise programs are most frequently prescribed for the treatment of knee OA after oral medications. ${ }^{[1]}$ The efficacy and importance of exercise therapy in the treatment of OA can be established. However, there are a limited number of studies in the literature about the effect on patients' compliances. ${ }^{[5-7]}$ This study was planned to understand the reasons for compliance with a home based exercise program with OA of the knee in elderly people.

The patients' exercise compliances seem to be lower than other medical regimens. Exercise compliance decreases over time and this is mostly due to symptom relief. The lack of the long-term motivation and control mechanisms affect compliance..$^{[4,12,13]}$ Schneiders ${ }^{[12]}$ reported a $38.1 \%$ compliance rate to home based exercise in cases of acute low back pain. Reported mean percentage compliance to exercise regimen in control group of chronic back pain was 30\%. ${ }^{[14]}$ In another study, compliance rates for exercise programs for patients with limb injuries were $74 \%$. Bassett ${ }^{[15]}$ reported compliance ranged from 20 to $60 \%$ in physiotherapy programme. But, compliance to home exercise programs in elderly people has been found to be limited. A recent systematic review of randomized controlled trials of home exercise programs found that a range of $15-29 \%$ of elderly populations were fully compliant to their prescribed home based exercise program. ${ }^{[16]}$ One study found that compliance rates for home exercise programs in elderly people at high risk of locomotor dysfunction ranged from 82.1 to $85.4 \%{ }^{[17]}$ In our study, we found that $62.5 \%$ of the elderly patients with knee OA study were compliant with home based exercise program.

There are a lot of studies in the literature which show that compliance of musculoskeletal pain treatment is a

Table 2. Characteristics of compliance

\begin{tabular}{lc}
\hline & Compliance (\%) \\
\hline Gender & \\
$\quad$ Female & 55.6 \\
$\quad$ Male & 83.3 \\
Education & \\
$\quad$ Low ( $<8$ years) & 64 \\
$\quad$ High ( $>8$ years) & 55 \\
Comorbidity & \\
$\quad$ Single disease & 71.4 \\
$\quad$ More than one disease & 58.8 \\
\hline
\end{tabular}


Table 3. Comparison of the assessment parameters in both groups

\begin{tabular}{|c|c|c|c|c|c|c|c|c|c|c|c|}
\hline & \multicolumn{5}{|c|}{ Noncompliance group $(\mathrm{n}=27)$} & \multicolumn{5}{|c|}{ Compliance group $(\mathrm{n}=45)$} & \multirow[b]{2}{*}{$p$} \\
\hline & $\mathrm{n}$ & $\%$ & Mean \pm SD & Median & Min.-Max. & $\mathrm{n}$ & $\%$ & Mean \pm SD & Median & Min.-Max. & \\
\hline Age (years) & & & $71.6 \pm 6.0$ & 70 & $65-83$ & & & $70 \pm 4.6$ & 68 & $62-82$ & 0.575 \\
\hline Exercise duration (min) & & & $10.4 \pm 5.7$ & 10 & $0-20$ & & & $16.8 \pm 7.3$ & 15 & $5-35$ & $0.001^{*}$ \\
\hline Gender & & & & & & & & & & & $0.035^{\star}$ \\
\hline Female & 24 & 89 & & & & 30 & 67 & & & & \\
\hline Male & 3 & 11 & & & & 15 & 33 & & & & \\
\hline Education & & & & & & & & & & & 0.482 \\
\hline Low ( $<8$ years $)$ & 19 & 70 & & & & 35 & 78 & & & & \\
\hline High ( $>8$ years) & 8 & 30 & & & & 10 & 22 & & & & \\
\hline Previous history of exercise & & & & & & & & & & & $0.002^{*}$ \\
\hline Yes & 2 & 7 & & & & 19 & 42 & & & & \\
\hline No & 25 & 93 & & & & 26 & 58 & & & & \\
\hline Comorbidity & & & & & & & & & & & 0.424 \\
\hline Single disease & 6 & 22 & & & & 15 & 33 & & & & \\
\hline More than one disease & 21 & 78 & & & & 30 & 67 & & & & \\
\hline
\end{tabular}

SD: Standard deviation; ${ }^{*} \mathrm{p}<0.05$; Min.: Minimum; Max.: Maximum.

complex question and depends on multiple variables, such as sociodemographic properties, characteristics of illness and type of regimen. Also the behavior of the patient and the therapist are important factors. ${ }^{[13,15,18,19]}$ The results of the studies which investigate the effectiveness of these factors on compliance of home exercise programs in knee OA patients are controversial. ${ }^{[15,19]}$ Among the factors we investigated were demographic variables, comorbidity and previous history of exercise. Moore et al. ${ }^{[20]}$ found that there was high compliance among men in cardiac rehabilitation. Similarly, various studies showed that females have a poorer compliance rate than male patients. ${ }^{[4,21]}$ On the other hand, Sluijs et al., ${ }^{[19]}$ found no difference between men and women regarding patient compliance. In our study, $83 \%$ of the men and $55 \%$ of the women were compliant and these results support the relation between compliance and gender.

Contradictory results have been reported about the relation between compliance and education level. ${ }^{[4,19]}$ One study found that highly educated patients were less compliant with exercise than lower educated patients. ${ }^{[19]}$ However, Hartigan et al. ${ }^{[22]}$ reported no relationship between compliance of back pain exercise program and education. The presence of comorbidity was significantly associated with poor compliance. $^{[4]}$ Lieberman et al. ${ }^{[23]}$ emphasized that comorbidity was found to be a strong predictor of poor compliance. In our study high educational attainment and comorbidity were also associated with poor compliance. It was shown that the compliances of the patients who previously had an exercise habit were better than the ones having no exercise practice before. ${ }^{[24]}$ Our results are similar to other studies. ${ }^{[6]}$ The results of the studies investigating the relation between compliance and age were conflicting. Older patients were slightly more compliant than younger patients but in another study, people over 65 years old were found to be less compliance than the young ones. ${ }^{[19,25]} \mathrm{We}$ found no statistically significant differences between compliance and age.

Our study would have been stronger had we evaluated the characteristics of the prescribed regimen and patients' and therapists' behavior. Patients' attitudes and physical therapist's behavior are related to compliance. ${ }^{[15,19]}$ The complex and long-term programs result with poorer adherence rates than simple exercise programs. The patients with acute and serious diseases with high disabilities have more compliance compared to less serious disorders. ${ }^{[5,6]}$ Exercises performed under supervision of the physiotherapist and motivation of the patient increases compliance. ${ }^{[12]}$ One study found that self directed home exercise with regular telephone contact improved physical function and quality of life. ${ }^{[17]}$ Moran ${ }^{[26]}$ reported digital video disc technology has been used to provide training for elderly people and has shown generally positive effects in increasing compliance to home exercise programs. In another study, home based exercise programs including telephone or home visit support applied by a physiotherapist were found to be partially compliant in a greater proportion of elderly population. ${ }^{[16]}$ In our study, we did not use this type of control method for assessing the compliance of elderly patients.

The objective measurement of compliance in home-based exercise programs is difficult due to the lack of standard measurement methods. Also objective 
methods are generally impractical, expensive and difficult to manage. In the assessment of compliance, subjective methods like patients' diaries and self reported questionnaires are mostly applied. These methods are both easy and cost-effective. However they may tend to overestimate compliance as they are based on the patients' answers. ${ }^{[4,5,12]}$ We also used subjective methods in our study and this was a limitation of our study. Another major limitation of this study was the small sample size. Power analysis and sample-size calculation in trials should always be considered at the beginning of the research study, which was a third limitation of our study.

The results of our study confirmed that the evaluation of home-based exercise programs in the geriatric population is both difficult and complex. The lack of a standard measurement method and the affects of the multiple variables on compliance make the measurements more difficult.

\section{Acknowledgments}

We wish to thank Dr. Can Ateş for his advice on statistical analyses.

\section{Declaration of conflicting interests}

The authors declared no conflicts of interest with respect to the authorship and/or publication of this article.

\section{Funding}

The authors received no financial support for the research and/or authorship of this article.

\section{REFERENCES}

1. Sadosky AB, Bushmakin AG, Cappelleri JC, Lionberger DR. Relationship between patient-reported disease severity in osteoarthritis and self-reported pain, function and work productivity. Arthritis Res Ther 2010;12:162.

2. Fernandes L, Hagen KB, Bijlsma JW, Andreassen O, Christensen P, Conaghan PG, et al. EULAR recommendations for the non-pharmacological core management of hip and knee osteoarthritis. Ann Rheum Dis 2013;72:1125-35.

3. Quintrec JL, Verlhac B, Cadet C, Bréville P, Vetel JM, Gauvain JB, et al. Physical exercise and weight loss for hip and knee osteoarthritis in very old patients: a systematic review of the literatüre. Open Rheumatol J 2014;8:89-95.

4. Alexandre NM, Nordin M, Hiebert R, Campello M. Predictors of compliance with short-term treatment among patients with back pain. Rev Panam Salud Publica 2002;12:86-94.

5. Henry KD, Rosemond C, Eckert LB. Effect of number of home exercises on compliance and performance in adults over 65 years of age. Phys Ther 1999;79:270-7.

6. Rejeski WJ, Brawley LR, Ettinger W, Morgan T, Thompson C. Compliance to exercise therapy in older participants with knee osteoarthritis: implications for treating disability. Med Sci Sports Exerc 1997;29:977-85.
7. Asmidawati A, Hamid TA, Hussain RM, Hill KD. Home based exercise to improve turning and mobility performance among community dwelling older adults: protocol for a randomized controlled trial. BMC Geriatr 2014;14:100.

8. Jakobsen MD, Sundstrup E, Brandt M, Kristensen AZ, Jay $\mathrm{K}$, Stelter R, et al. Effect of workplace- versus home-based physical exercise on pain in healthcare workers: study protocol for a single blinded cluster randomized controlled trial. BMC Musculoskelet Disord 2014;15:119.

9. Altman R, Asch E, Bloch D, Bole G, Borenstein D, Brandt $\mathrm{K}$, et al. Development of criteria for the classification and reporting of osteoarthritis. Classification of osteoarthritis of the knee. Diagnostic and Therapeutic Criteria Committee of the American Rheumatism Association. Arthritis Rheum 1986;29:1039-49.

10. Kellgren JH, Lawrence JS. Radiological assessment of osteoarthrosis. Ann Rheum Dis 1957;16:494-502.

11. Tallon D, Chard J, Dieppe P. Exploring the priorities of patients with osteoarthritis of the knee. Arthritis Care Res 2000;13:312-9.

12. Schneiders AG, Zusman M, Singer KP. Exercise therapy compliance in acute low back pain patients. Man Ther 1998;3:147-52.

13. Campbell R, Evans M, Tucker M, Quilty B, Dieppe P, Donovan JL. Why don't patients do their exercises? Understanding non-compliance with physiotherapy in patients with osteoarthritis of the knee. J Epidemiol Community Health 2001;55:132-8.

14. Spelman MR. Back pain: how health education affects patient compliance with treatment. Occup Health Nurs 1984;32:649-51.

15. Bassett SF. The assessment of patient adherence to physiotherapy rehabilitation. NZ J Phys 2003;31:60-6.

16. Simek EM, McPhate L, Hill KD, Finch CF, Day L, Haines TP. What Are the Characteristics of Home Exercise Programs That Older Adults Prefer?: A Cross-Sectional Study. Am J Phys Med Rehabil 2015;94:508-21.

17. Aoki K, Sakuma M, Ogisho N, Nakamura K, Chosa E, Endo $\mathrm{N}$. The effects of self-directed home exercise with serial telephone contacts on physical functions and quality of life in elderly people at high risk of locomotor dysfunction. Acta Med Okayama 2015;69:245-53.

18. Friedrich M, Gittler G, Halberstadt Y, Cermak T, Heiller I. Combined exercise and motivation program: effect on the compliance and level of disability of patients with chronic low back pain: a randomized controlled trial. Arch Phys Med Rehabil 1998;79:475-87.

19. Sluijs EM, Kok GJ, van der Zee J. Correlates of exercise compliance in physical therapy. Phys Ther 1993;73:771-82.

20. Moore SM, Ruland CM, Pashkow FJ, Blackburn GG. Women's patterns of exercise following cardiac rehabilitation. Nurs Res 1998;47:318-24.

21. Von Korff M, Deyo RA, Cherkin D, Barlow W. Back pain in primary care. Outcomes at 1 year. Spine (Phila Pa 1976) 1993;18:855-62.

22. Hartigan C, Rainville J, Sobel JB, Hipona M. Long-term exercise adherence after intensive rehabilitation for chronic low back pain. Med Sci Sports Exerc 2000;32:551-7. 
23. Lieberman L, Meana M, Stewart D. Cardiac rehabilitation: gender differences in factors influencing participation. J Womens Health 1998;7:717-23.

24. Stenström $\mathrm{CH}$, Arge B, Sundbom A. Home exercise and compliance in inflammatory rheumatic diseases--a prospective clinical trial. J Rheumatol 1997;24:470-6.

25. Lorenc L, Branthwaite A. Are older adults less compliant with prescribed medication than younger adults? Br J Clin Psychol 1993;32:485-92.

26. Moran L, Francis-Coad J, Patman S, Hill AM. Using a personalized DVD to prescribe an exercise program to older people post-hip fracture enhances adherence to the exercises - A feasibility study. Geriatr Nurs 2015;36:273-80. 